\title{
DERECHO AL MATRIMONIO Y DIVERSIDAD FAMILIAR
}

\author{
OCTAVIO SALAZAR BENÍTEZ
}


SUMARIO

1. LA CONSTITUCIONALIDAD DEL MATRIMONIO IGUALITARIO. 1.1. La necesaria interpretación dúctil del art. 32 CE. 1.2. Matrimonio e igualdad de reconocimiento. 2. EL MATRIMONIO COMO «GARANTÍ́A INSTITUCIONAL»DEL PATRIARCADO. 2.1. Heteronormatividad y ciudadanía. 2.2. Las voces plurales del movimiento LGTB. 2.3. Los efectos «normalizadores» del matrimonio. 3. EL LIBRE DESARROLLO DE LA AFECTIVIDAD Y LA SEXUALIDAD COMO PRESUPUESTO DE LA DIVERSIDAD FAMILIAR. 4. AUTONOMÍA Y DIVERSIDAD: LOS EJES DE UNA NUEVA CONCEPCIÓN DEL DERECHO DE FAMILIA. 


\title{
DERECHO AL MATRIMONIO Y DIVERSIDAD FAMILIAR ${ }^{1}$
}

\author{
OCTAVIO SALAZAR BENÍTEZ ${ }^{2}$
}

\section{LA CONSTITUCIONALIDAD DEL MATRIMONIO IGUALITARIO}

\subsection{La necesaria interpretación dúctil del art. $32 C E$}

Una de las mayores polémicas de la VIII legislatura fue la relacionada con la reforma del Código Civil llevada a cabo a través de la Ley 13/2005, de 1 de julio, la cual reconoció el matrimonio entre personas del mismo sexo. Desde el punto de vista jurídico-constitucional la controversia, plasmada en el recurso de inconstitucionalidad planteado por el Grupo Parlamentario Popular ${ }^{3}$, se centró en la interpretación del art. $32 \mathrm{CE}^{4}$. La polémica puede reconducirse a dos posi-

${ }^{1}$ Una primera versión de este trabajo fue enviada el 9 de diciembre de 2011 para su publicación en el libro homenaje a Antonio Torres del Moral. Debido a un lamentable error, no se incluyó en dicha obra y por este motivo se incluye en este número de la Revista, con las debidas actualizaciones.

${ }^{2}$ Profesor Titular de Derecho Constitucional de la Universidad de Córdoba. Correo electrónico: octavio@uco.es. Blog:www.lashoras-octavio.blogspot.com

${ }^{3}$ El recurso fue presentado el 28 de septiembre de 2005 y se apoyó en la violación de un total de 9 preceptos constitucionales (los artículos 32, 10.2, 14, 1.1, 9.2, 39, 53.1, 9.3 y 167). La base de su argumentación fue la defensa del matrimonio como una «garantía institucional», de la que la heterosexualidad forma parte y marca por tanto un límite para el legislador.

${ }^{4}$ Hay que tener en cuenta que «en el mundo de la democracia liberal, hoy por hoy dista de existir un consenso mínimo sobre la respuesta constitucional que debe darse al matrimonio entre personas del mismo sexo». DÍEZ PICAZO, L. M. «En torno al matrimonio entre personas del 
ciones: a) La heterosexualidad es un factor esencial del matrimonio, por lo que las uniones entre personas del mismo sexo deberían revestir otra forma jurídica; b) Sólo desde posiciones morales o religiosas es posible seguir defendiendo que la heterosexualidad, y ligada a ella la finalidad de la procreación ${ }^{5}$, es esencial en el matrimonio, por lo que cabría extenderlo a las uniones entre personas del mismo sexo. Una interpretación avalada por la misma Carta Europa de Derechos Fundamentales en la que el derecho al matrimonio se contempla de manera impersonal, sin hacer referencia expresa al sexo de los contrayentes ${ }^{6}$.

La primera posición la encontramos reflejada en los dictámenes del Consejo de Estado y del Consejo General del Poder Judicial en relación al Anteproyecto de Ley de reforma del Código Civil, emitidos respectivamente el 16 de diciembre de 2004 y el 26 de enero de 2005. Ambos se apoyan en la doctrina mantenida por el Tribunal constitucional español, según la cual la heterosexualidad es un elemento esencial del matrimonio, por lo que el derecho del art. $32 \mathrm{CE}$ sólo cabe entenderlo como referido a la unión de personas del sexo opuesto (ATC 222/1994, de 11 de julio) ${ }^{7}$. Lo expresa con rotundidad el Consejo General del Poder Judicial: «... la heterosexualidad es un elemento constitutivo esencial del propio concepto de matrimonio: el matrimonio o es heterosexual o no es» (cursiva mía).

Estoy de acuerdo con Pérez Cánovas cuando afirma que «la defensa del requisito de la heterosexualidad en el matrimonio, consciente o inconscientemente, sólo es reconducible al argumento, científicamente refutado, de que las relaciones homosexuales son relaciones "contra natura" al excluir por hipótesis la procreación» ${ }^{8}$. Por lo tanto, detrás de las posiciones en contra de la

mismo sexo», InDret. Revista para el análisis del Derecho. Núm. 2, 2007, pág. 8 (consultado en www. indret.com, 2-10-2011).

5 Es lo que defiende con rotundidad el Informe emitido por la Real Academia de Jurisprudencia y Legislación acerca del Proyecto de modificación del Código civil en materia de matrimonio: «La función social del matrimonio consiste en ser el momento fundacional de una familia entendida como progenie (...) por eso, la pretensión de extenderlos a las uniones homosexuales significaría no una excepción sino una negación de este principio rector».

${ }^{6}$ En concreto, al art. 9 habla de manera impersonal del derecho a contraer matrimonio y fundar una familia, a diferencia de textos internacionales anteriores en los que sí que se hace referencia expresa al hombre y la mujer como sujetos del derecho. Es el caso del art. 16 de la Declaración Universal de Derechos del Hombre o del art. 12 de la Convención Europea de Derechos Humanos.

7 El TC confirmaba así las tesis mantenidas con anterioridad por el Tribunal Supremo (sentencia de 19 de abril de 1991), así como por la Dirección General de los Registros y el Notariado. Ésta, en una resolución de 21 de enero de 1988, denegó la pretensión de dos hombres de inscribir su unión como matrimonio en el Registro Civil.

8 PÉREZ CÁNOVAS, N. Homosexualidad, homosexuales y uniones homosexuales en el Derecho español. Granada, Comares, 1996, pág. 130. 
reforma está presente una concepción que nos remite a la construcción de los géneros propia del patriarcado. Desde el momento en que la heterosexualidad se convierte en ingrediente esencial del matrimonio, y de ello deducimos que su razón última es la procreación ${ }^{9}$, se está defendiendo un determinado papel de los hombres y de las mujeres así como una determinada configuración de los espacios privados ${ }^{10}$. Por ello me parecen censurables las posiciones que apoyan la superioridad de la función social del matrimonio en su carácter de «comunidad procreadora o de paternidad/maternidad potencial» ${ }^{11}$. Entre otras cosas porque, como bien llama la atención Luis M. ${ }^{a}$ Díez-Picazo, «en los últimos decenios la perpetuación de la especie ha dejado de depender exclusivamente del acto sexual entre hombre y mujer. Una vez que la reproducción humana es posible por otras vías, no es de extrañar — cualquiera que sea la valoración moral que a cada uno le merezca - que la ancestral exigencia de diversidad entre los cónyuges se tambalee» ${ }^{12}$.

Los argumentos usados en contra de la reforma del Código Civil nos demuestran que «cuando se trata de parejas homosexuales, entonces el jurista se desliza con facilidad en el terreno de la ética y de la biología, de la pedagogía, la religión y la moral. Y vierte sobre ellos todos sus prejuicios. Sino pecadores, tal vez enfermos o, al menos, promiscuos, con respecto a los cuales el reconocimiento y la protección legal sólo puede producir un peligro para la especie, la familia y la sociedad $»^{13}$.

Frente a esa posición, considero más ajustado a la dignidad y a la autonomía del individuo entender que el matrimonio es un cauce jurídico que garantiza derechos y obligaciones en condiciones de igualdad pero también, y principal-

9 «Para que pueda haber consentimiento matrimonial, es necesario que los contrayentes no ignoren al menos que el matrimonio es un consorcio permanente entre un varón y una mujer, ordenado a la procreación de la prole mediante una cierta cooperación sexual» (Canon 1096 Código de Derecho Canónico)

10 El Consejo General del Poder Judicial lleva a tal extremo esta posición que incluso utiliza como argumento la referencia del art. 58 CE a «la Reina consorte o el consorte de la Reina...» Dice el CGPJ que «es manifiesto que la Constitución vuelve a pensar en una unión heterosexual y cabe sostener que del mismo modo que una hipótesis contraria referida a la Familia Real sería tan inasumible como la generalización al resto de las familias, ex art. 32.1, del matrimonio entre personas del mismo sexo». De esta manera, el CGPJ llega a considerar como inaceptable por nuestro sistema constitucional que el Rey o la Reina puedan ser homosexuales.

11 REY MARTÍNEZ, F. «Homosexualidad y Constitución», Revista Española de Derecho Constitucional. N 73, enero-abril 2005, pág. 149.

12 DÍEZ PICAZO, L. M. ${ }^{a}$ «En torno al matrimonio entre personas del mismo sexo», cit, pág. 12.

13 SÁNCHEZ MARTÍNEZ, M. ${ }^{a}$ O. Igualdad sexual y diversidad familiar: ¿ La familia en crisis?, Madrid, Universidad de Alcalá, 2010, págs. 102-103. 
mente, una proyección del libre desarrollo de la afectividad y de la sexualidad ${ }^{14}$. Es decir, la clave para defender la constitucionalidad de la reforma de nuestra legislación civil estaría en la vinculación del matrimonio con el libre desarrollo de la personalidad o, dicho de otra manera, en su concepción más que como «garantía institucional» como «derecho subjetivo» ${ }^{15}$. Ello desde el entendimiento de que el art. $32 \mathrm{CE}$ «impide al legislador suprimir el matrimonio entre hombre y mujer; pero, como no prefigura otros posibles rasgos de la institución, habrá que concluir que también no impide al legislador ampliar la institución matrimonial a las parejas del mismo sexo» ${ }^{16}$.

Esta fue finalmente la interpretación que mantuvo el Tribunal Constitucional, el cual se pronunció siete años — ¡siete! — después de la interposición del recurso en su sentencia 198/2012, de 6 de noviembre. El TC mantuvo que la reforma de 2005 «no afecta al contenido esencial del derecho, porque el que puedan contraer matrimonio entre sí personas del mismo sexo ni lo desnaturaliza, ni lo convierte en otro derecho, ni impide a las parejas heterosexuales casarse libremente, o no casarse ${ }^{17}$. La misma sólo implica que las personas homosexuales puedan contraer matrimonio, lo cual supone dar un paso «en la garantía de la dignidad de la persona y el libre desarrollo de la personalidad (art. 10.1 CE) que han de orientarse a la plena efectividad de los derechos fundamentales». Por otra parte, entiende el TC que no le corresponde a él enjuiciar la oportunidad o conveniencia de la elección hecha por el legislador al regular la convivencia de las parejas del mismo sexo.

El TC basa su argumentación en la interpretación del la Constitución como «un árbol vivo», siguiendo el concepto acuñado en una sentencia de la Corte

14 Por eso me resulta tan sorprendente que en el Informe emitido por la Real Academia de Jurisprudencia y Legislación, y en el que se defendió que el art. 32 CE contiene una garantía institucional del matrimonio como unión entre un hombre y una mujer, se diga literalmente que «desde el punto de vista jurídico no puede decirse que el matrimonio sea un instrumento para dar cauce a la afectividad de las personas (...) lo que se garantiza con el matrimonio es un compromiso de vida común y que es independiente de las relaciones de afectividad, porque éstas pertenecen al terreno de la intimidad».

15 En este sentido, véase Martín Sánchez, M. Matrimonio homosexual y Constitución. Valencia, Tirant lo Blanch, 2008.

16 DÍEZ PICAZO, L. M. ${ }^{a}$ «En torno al matrimonio entre personas del mismo sexo», cit., pág. 11 .

17 Con respecto a cuál fue la voluntad del constituyente al redactar el art. 32 CE, la sentencia deja muy claro que aquel pretendía afianzar «la igualdad entre el hombre y la mujer, sin resolver otras cuestiones, lo cual no significa que implícitamente acogiera el matrimonio entre personas del mismo sexo, si nos limitamos a realizar una interpretación literal y sistemática, pero tampoco significa que lo excluyera» (FJ 8). 
Suprema de Canadá de 9 de diciembre de 2004. De ahí la necesidad de acoger una interpretación evolutiva y basada en la «observación de la realidad social jurídicamente relevante» ${ }^{18}$. Por otra parte, se entiende que la ley 13/2005 desarrolla la institución del matrimonio conforme a nuestra cultura jurídica, sin hacerla en absoluto irreconocible para la imagen que de la institución se tiene en la sociedad contemporánea. Es decir, «la institución matrimonial se mantiene en términos perfectamente reconocibles por la imagen que tenemos en la sociedad española actual del matrimonio, como comunidad de afecto que genera un vínculo, o sociedad de ayuda mutua entre dos personas que poseen idéntica posición en el seno de esta institución, y que voluntariamente deciden unirse en un proyecto de vida familiar común, prestando su consentimiento respecto de los derechos y deberes que conforman la institución y manifestándolo expresamente mediante las formalidades establecidas en el ordenamiento» ${ }^{19}$.

\subsection{Matrimonio e Igualdad de reconocimiento}

Una vez avalada la constitucionalidad de la Ley 13/2005, mi interés en las páginas siguientes no se va a centrar en abordar el debate jurídico en torno a la interpretación del art. $32 \mathrm{CE}$, sino en plantear una reflexión en torno a su oportunidad y en cuanto a los efectos que ha supuesto en la garantía del derecho al libre desarrollo de la afectividad y la sexualidad. En realidad, ambos debates están conectados ya que los argumentos jurídicos en torno a la naturaleza del matrimonio pueden servirnos para plantearnos las dudas que suscita la extensión de un modelo de convivencia diseñado de acuerdo con los intereses de la mayoría heterosexual. Al mismo tiempo es necesario analizar las razones políticas que llevaron a dicha reforma así como las posiciones que al respecto han mantenido diferentes sectores del movimiento de lesbianas, gays, transexuales y bisexuales (en adelante, LGTB).

${ }^{18}$ En este sentido cabe destacar cómo el TC usa para apoyar su argumentación no sólo el progresivo reconocimiento del matrimonio igualitario en el Derecho comparado sino también los datos sociológicos que demuestran su amplia aceptación social.

19 Cuatro magistrados (Rodríguez Arribas, Ollero, Aragón, González Rivas) formularon sendos votos particulares en los que se insiste, con distintos matices, en considerar que la reforma de 2005 incide en el núcleo de la «garantía institucional» que supone el art. 32 CE. Cabe destacar los matices que aporta Manuel Aragón Reyes con respecto al significado y uso de la «interpretación evolutiva». Mediante ella, sostiene el magistrado, no puede hacérsele decir a la norma lo contrario de lo que se dice: entonces se cambia la Constitución. Es decir, ello implica una actuación del TC no como poder constituido sino como poder constituyente. 
Este debate debemos situarlo además en un contexto de transformaciones sociales, políticas y culturales que están poniendo en entredicho algunos de los paradigmas del constitucionalismo, muy especialmente la construcción universalista de la dignidad basada en los principios de legalidad e igualdad formal ante la ley. Las reivindicaciones identitarias —entre las que también podríamos situar las relativas al género o a la sexualidad- están planteando una serie de interrogantes a un Derecho de tendencias asimilacionistas, poco flexible, ciego a las diferencias y prisionero de unas interpretaciones excesivamente formalistas y rígidas. De ello podría ser un magnífico ejemplo la defensa del matrimonio como «garantía institucional», lo cual supone su «petrificación» en unos esquemas no sólo jurídicos, sino también socio-culturales, que dificultan una lógica extensiva y diferenciada de los derechos.

En estas reflexiones el feminismo ha de servirnos de marco de referencia teórico. No cabe ninguna duda de que, no sólo como movimiento reivindicativo sino también como teoría política, el feminismo ha contribuido de manera singular a la progresiva deconstrucción de un orden social y cultural, el del patriarcado, que durante siglos ha determinado la posición de hombres y mujeres. No sólo ha sido clave en la profundización del principio de igualdad, sino también, y principalmente, en la erosión de una cultura patriarcal que ha condicionado el ejercicio de la ciudadanía. Ese orden se ha articulado sobre estructuras binarias de carácter jerárquico —-Masculino/femenino, Público/privado, Cultura/naturaleza-, las cuales también han tenido su expresión en el ámbito de la afectividad y la sexualidad. En este sentido, podemos afirmar que el orden patriarcal ha sido y es un orden heterosexista, es decir, ha convertido en canon de normalidad la heterosexualidad y ha invisibilizado otras opciones sexuales, considerándolas desde crímenes contra natura a, en el mejor de los casos, preferencias que se debían mantener en el ámbito privado y sin reconocimiento social. Todo ello, a su vez, se ha traducido en una determinada concepción socio-cultural del amor y, por supuesto, de la familia ${ }^{20}$.

Por lo tanto, cuando hablamos del matrimonio tenemos que enmarcarlo necesariamente en ese contexto cultural. Debemos interpretarlo como la traducción jurídica del «contrato sexual» ${ }^{21} y$, en consecuencia, como configurador no sólo de un determinado estatuto para los hombres y para las mujeres, sino también como factor simbólico generador de pautas sociales y de consecuencias eco-

${ }^{20}$ De ahí que «tanto para el feminismo como para el movimiento de liberación homosexual el matrimonio y la familia constituyen uno de los principales campos de acción para subvertir su situación de discriminación». PICHARDO, J. I. Entender la diversidad familiar. Relaciones homosexuales y nuevos modelos de familia. Barcelona, Bellaterra 2009, pág. 50.

${ }^{21}$ PATEMAN, C. El contrato sexual. Madrid, Anthropos, 1995. 
nómicas. Ello debe ser puesto en relación con los cambios sustanciales que los vínculos afectivos están sufriendo en nuestras sociedades, con la transformación del concepto de familia y su necesaria declinación en plural y, en consecuencia, con la revisión de realidades tan complejas como la filiación o el parentesco. Una reflexión que desde hace años se está haciendo desde ámbitos como el de la Antropología o la Sociología, pero a la que los juristas, como suele ser habitual, llegamos con retraso.

Al mismo tiempo, dicha reflexión no puede aislarse del debate en torno a si el reconocimiento del matrimonio supone una conquista que de alguna manera culmina la lucha y las reivindicaciones del colectivo LGTB o, por el contrario, es sólo un paso más que deberá completarse con otros muchos que pongan fin a la cultura «heteronormativa» dominante.

Este análisis debe partir necesariamente de la profundización en el principio de igualdad que nos lleve a asumir una de sus dimensiones esenciales, la denominada «igualdad de reconocimiento», y la correlativa asunción de la diferencia como un principio jurídico-político sin el que no es posible dar respuesta satisfactoria las exigencias de la dignidad y libre desarrollo de la personalidad. Igualdad, Dignidad y Libre Desarrollo de la Personalidad son las tres claves constitucionales que nos permiten no sólo avalar la constitucionalidad del matrimonio entre personas del mismo sexo sino también construir «en positivo», y no sólo desde la prohibición de discriminación, el que podemos llamar «derecho al libre desarrollo de la afectividad y la sexualidad ${ }^{22}$.

\section{EL MATRIMONIO COMO «GARANTIIA INSTITUCIONAL» DEL PATRIARCADO}

\subsection{Heteronormatividad y ciudadanía}

No podemos negar la importancia simbólica que supone que el ordenamiento jurídico amplíe el disfrute de un derecho a una parte de la ciudadanía que durante siglos fue excluida del mismo. Un derecho que, como sabemos, es esencial en la estructura de la sociedad al tiempo que juega un papel clave en

${ }^{22}$ Me parece mucho más omnicomprensivo este concepto que el de «orientación sexual», al que por ejemplo se refiere el Estatuto de autonomía de Andalucía en su art. 35. Dentro del libre desarrollo de la afectividad y la sexualidad habría que considerar incluida la «identidad de género» como un derecho específico que afecta de manera singular a las personas transexuales. Sobre este derecho véase SALAZAR BENÍTEZ, O. «El reconocimiento jurídico-constitucional de la diversidad afectiva y sexual», Revista de Estudios Políticos, núm. 157, 2012, págs. 45-81. 
el contexto de las relaciones personales y familiares. Por ello es justificable la paradoja que encierra la reivindicación del matrimonio, ya que éste, que «muchas veces ha sido considerado por los homosexuales como un instrumento de opresión, es actualmente reivindicado como un «símbolo de inclusión», que ha de permitirles el acceso a todos los derechos de la ciudadanía, ya que implica reconocimiento y aceptación social ${ }^{23}$.

Ahora bien, los efectos jurídicos podrían haber sido los mismos a través de una regulación de parejas no casadas o de cualquier otra fórmula contractual que permitiera reconocer las diversas opciones de convivencia. La diferencia estriba pues en el acceso a un contrato civil que está inserto en lo más profundo de la estructura social y simbólica, con todo lo que ello conlleva de equiparación y de superación de discriminaciones históricas. En este sentido, acceder al matrimonio es acceder a un coto vedado, a un término limitado a personas de distinto sexo (que no heterosexuales, necesariamente, puesto que había muchos homosexuales casados y por supuesto bisexuales antes de la reforma del 2005). En este caso, y como bien ha insistido el feminismo, el mismo lenguaje representa un instrumento de igualdad. El matrimonio ha servido históricamente para definir la posición en la sociedad, y desde esa perspectiva ahora también gays y lesbianas pueden revestirse con esa nomenclatura, pueden mostrarse «casados» ante la sociedad. Ahora el nombre también les pertenece. No son excluidos por el Código Civil, ni apartados en una regulación específica que incidiría en su consideración como «minoría».

Ahora bien, asumir el matrimonio implica también claudicar ante «la obligatoriedad heterosexual», y por lo tanto ser condescendientes con el sistema que ha discriminado constantemente a gays y lesbianas. Hay que tener en cuenta que la violencia más dura que sufren los homosexuales no es la física, que es la derivada, sino la simbólica, que es la originaria ${ }^{24}$. Y esta es consecuencia de un modelo patriarcal y heterosexual que ha tenido y tiene en la familia surgida del matrimonio una de sus bases esenciales ${ }^{25}$.

23 SÁNCHEZ MARTÍNEZ, M. ${ }^{a}$ O. Igualdad sexual y diversidad familiar..., cit., pág. 96.

24 VÉLEZ-PELLEGRINI, L. Minorías sexuales y sociología de la diferencia. Barcelona, Montesinos, 2008, pág. 20.

${ }^{25}$ Este sistema ha provocado que a lo largo de la historia, la sexualidad heterosexual haya sido considerada «natural, buena, necesaria, saludable y moralmente positiva, mientras que el resto de sexualidades son consideradas contra natura, malas, negativas, enfermas, moralmente censurables o pecaminosas» PICHARDO, J.I. Entender la diversidad familiar, cit., pág 143. En este sentido, no podemos negar que «la heterosexualidad ha venido siendo uno de los elementos básicos del orden público en materia matrimonial, al menos en Occidente». DÍEZ-PICAZO, L. M. ${ }^{a}$ «En torno al matrimonio entre personas del mismo sexo», cit., pág. 7. 
En nuestro país ha triunfado la que podríamos denominar posición «asimilacionista», frente a las que defendían otro tipo de alternativas, como una ley de parejas estables. Esta segunda opción suponía para los defensores del matrimonio «asumir un papel de matrimonio desimbolizado y, por lo tanto, de segunda categoría» ${ }^{26}$. Por el contrario, acceder al matrimonio implicaría una plena equiparación con los heterosexuales. En este sentido, se ha llegado incluso a considerar el matrimonio como «un acceso a la ciudadanía» ${ }^{27}$, lo cual pone de manifiesto la íntima conexión que todavía hoy sigue existiendo entre ella y la heteronormatividad, entre la definición del espacio público y los modelos patriarcales de convivencia. El gran error de este planteamiento es asumir que lo que supone una opción de cada individuo - la de optar por un determinado marco jurídico que regule su relación de pareja- se convierta en elemento definidor de un estatus, la ciudadanía, que ha de acoger en su seno la múltiples opciones, también afectivas y sexuales, de los ciudadanos. Habría que invertir, pues, los términos. Cualquier individuo, sin que sea discriminado por su sexo, raza, religión, opción sexual o cualquier otra circunstancia personal o social, debe tener reconocidos los derechos que garantiza el sistema constitucional (art. 14 CE). A partir de ese reconocimiento, cualquier ciudadano o ciudadana debe tener derecho a acceder a las fórmulas jurídicas que sean más respetuosas con su identidad y con el ejercicio de su autonomía. Conceptualizar el matrimonio como acceso a la ciudadanía llevaría al absurdo de excluir de la misma a todos los que no opten por dicho contrato.

Es evidente que el acceso al matrimonio, además de ser una opción con menos dificultades de técnica legislativa (se trata sólo de hacer extensivo lo previsto en el Código Civil a los supuestos en que los dos contrayentes sean del mismo sexo $)^{28}$, supone una equiparación absoluta con las parejas heterosexuales. En este sentido, implica un reconocimiento de igualdad de derechos, consecuencia de la conjunción obligada de los art. 14. 92 y 32 CE, además de un importante efecto simbólico en la sociedad. A ello habría que sumar el avance que supone en la progresiva «democratización» de la vida familiar en cuanto que rompe

26 VÉLEZ-PELLEGRINI, L. Minorías sexuales..., cit., pág. 229.

27 PICHARDO, J. J. Entender la diversidad familiar..., cit., pág. 136.

${ }^{28}$ Ello enlaza con la teoría de que la apertura del matrimonio a gays y lesbianas es una opción del legislador, que es el que puede modificar su «contenido esencial». Es la posición mantenida por el Tribunal Constitucional francés que en su decisión de 22 de enero de 2011 entendió que la prohibición del matrimonio entre personas del mismo sexo no violenta la Constitución y que es el legislador el que, en todo caso, debería reformar los artículos del Código Civil que mantienen que dicho contrato ha de celebrarse necesariamente entre un hombre y una mujer. 
con la división binaria y jerárquica entre los dos $\operatorname{sexos}^{29}$ : los que se unen son dos hombres o dos mujeres que parten de una posición jurídica, política y culturalmente igual.

Esta opción encaja además con el universalismo propio del Estado constitucional y con la tendencia a mantener invisibles, o en todo caso asimiladas, las diferencias. De esta manera, se alcanza un efecto de «normalización» con toda la carga positiva y negativa que conlleva ese término.De esta forma, y paradójicamente, se anulan incluso los argumentos de los que se opusieron al matrimonio gay por considerar que su reconocimiento poner en crisis un determinado modelo de familia. Más bien al contrario, su reconocimiento ha consolidado la familia y la ha ampliado en un doble sentido. Por una parte, se trata de una reforma legislativa que extiende derechos y que no afecta a derechos de «terceros». Es decir, los matrimonios heterosexuales seguirán celebrándose, procreando y prorrogando en mayor o menor medida los roles tradicionales, sin que se vean afectados porque los gays y las lesbianas también puedan hacerlo ${ }^{30}$. En segundo lugar, estos vienen a conformar nuevas familias que se suman a las anteriores. De esta manera, la cuestión que plantea la reforma del 2005 no es tanto el peligro que podría suponer para la familia tradicional, sino la diversidad de opciones que está cambiando lo que hasta hacer relativamente poco tiempo era un modelo homogéneo. Una diversidad que, recordemos, está amparada constitucionalmente desde el momento en que la protección de la familia —art. 39 CE_ se desvincula del derecho al matrimonio — art. 32 CE (STC 222/1992, de 11 de diciembre).

\subsection{Las voces plurales del movimiento LGTB}

No deberíamos olvidar que en otros contextos las reivindicaciones del movimiento LGTB no se han centrado en el derecho al matrimonio. Es el caso por ejemplo del movimiento gay y lesbiano norteamericano y británico, que más

29 MARTÍNEZ, M. ${ }^{\text {a }}$ O. Igualdad y diversidad familiar..., cit., pág. 99.

${ }^{30}$ Lo apunta con rotundidad la STC 198/2012 en su FJ 11: «Las personas heterosexuales no han visto reducida la esfera de libertad que antes de la reforma tenían reconocida como titulares del derecho al matrimonio, puesto que con la regulación actual y con la anterior, gozan del derecho a contraer matrimonio sin más limitaciones que las que se deriven de la configuración legal de los requisitos para contraer matrimonio que realiza el Código Civil. Sin embargo, las personas homosexuales gozan ahora de la opción, inexistente antes de la reforma legal, de contraer matrimonio con personas del mismo sexo, de tal modo que el respeto a su orientación sexual encuentra reflejo en el diseño de la institución matrimonial, y por tanto su derecho individual a contraer matrimonio integra también el respeto a la propia orientación sexual». 
bien han defendido una legislación específica. Vélez-Pellegrini pone en relación estos posicionamientos con la cultura política de cada país. Así, «en realidades nacionales en las que la política de la diferencia ha sido de tradicional aplicación en el espacio público, las medidas «diferenciadas» en beneficio de las minorías apenas suscita recelo o protesta». Por el contrario, «en países como España, con una cultura política y una tradicional constitucional muy próxima a los clásicos valores del universalismo igualitarista, una política «diferencial» se ha visto en cambio mal aceptada por los colectivos gays y lesbianos más moderados y reformistas ${ }^{31}$.

Algo similar ha venido a ocurrir en Francia, un país también marcado en lo jurídico por una lógica universalista y homogeneizadora, si bien a través de un distinto recorrido. En el año 1999 se introdujo en el Código civil un instrumento jurídico alternativo al matrimonio y que permite reconocer a las parejas no casadas, el conocido como Pacto Civil de Solidaridad. Además de que en muchos de sus aspectos se utilizan de manera analógica las reglas del matrimonio, las sucesivas reformas han ido acercándolo cada vez más al régimen de aquél. De esta manera, se ha llegado a producir una creciente «matrimonialización» del contrato, lo que ha dado lugar a «la imposición de reglas coercitivas incluso a quienes, no casándose, aspiraban a una organización informal y espontánea de su intimidad $»^{32}$. Finalmente, esta evolución ha llevado a que también el país vecino opte por la regulación del matrimonio igualitario ${ }^{33}$.

En nuestro país, más allá del debate político y jurídico en torno a la constitucionalidad de la reforma del Código Civil, ha faltado una reflexión sobre los modelos de convivencia y sobre las transformaciones que está experimentando la familia tradicional. Y, sobre todo, resulta sorprendente que determinados sectores del movimiento LGTB hayan puesto el acento en mantener ese imaginario, en cuanto que contribuye a reforzar una cultura que tradicionalmente ha discriminado a las opciones no heterosexuales ${ }^{34}$.

31 VÉLEZ-PELLEGRINI, L. Minorías sexuales y sociología de la diferencia, cit., págs. 300-301.

32 BORRILLO, D. «El pacto civil de solidaridad: ¿contractualización del matrimonio o matrimonialización de la convivencia more uxorio?", Derecho de familia, núm. 46, julio-agosto 2010, pág. 47.

33 El Parlamento francés aprobó el 22 de febrero de 2013 la ley del matrimonio igualitario, la cual está pendiente, en el momento de cerrar este texto, de votación en el Senado, la cual está prevista para el 2 de abril de 2013.

34 «Algunos parecen haber olvidado que «la lucha gay y lesbiana, al menos en sus orígenes como movimiento social, remitió sobre todo a la libertad del actor social frente a la presión del sistema histórico y sus representaciones culturales. Es precisamente esa cultura libertadora, anti-dicotómica, anti-género y, por lo tanto, antidominadora, la que parece estar en cuestión». VÉLEZ-PELLEGRINI, L. Minorías sexuales y sociología de la diferencia, cit., pág. 367. En esa línea 
Llama la atención como el debate en torno a la reforma del Código Civil, más allá de las dudas de su constitucionalidad y de la confrontación política (y moral) generada por la propuesta del gobierno socialista, no generara una reflexión más plural y profunda sobre la garantía de los derechos del colectivo LGTB. Quizás ese haya sido el precio a pagar por una cierta «institucionalización» del movimiento gay, lo cual ha posibilitado que determinadas demandas se situaran en la agenda política, pero también ha provocado una simplificación de las reivindicaciones y su acomodo a las prioridades e intereses de los principales actores políticos.

Debemos recordar que durante muchos años el movimiento gay español concentró su atención casi exclusivamente en la reivindicación de una ley de parejas de hecho. La mayoría de los partidos españoles respaldaron, con mayor o menor intensidad y compromiso, la necesidad de una legislación de este tipo. Así se puede explicar el intenso devenir parlamentario de este tema entre 1997 y 1998, así como las numerosas leyes autonómicas de parejas de hecho aprobadas en nuestro país en ese período ${ }^{35}$. Sin embargo, a partir de 1997 el sector mayoritario del movimiento decidió centrarse en la reivindicación del derecho al matrimonio. Frente a las posiciones del Partido Popular, que pretendía identificar la unión no casada con la mera convivencia, era necesario dejar claro que lo que se demandaba era cobertura jurídica para unas uniones estables y duraderas. Pero más que el cambio que se produjo en buena parte del movimiento LGTB, fue más significativo el experimentado por el PSOE. No fue hasta después de la derrota electoral de 1996 cuando el partido socialista asumió las demandas del colectivo en su intento de presentarse a la sociedad con un proyecto político renovado ${ }^{36}$.

Por otra parte, no podemos perder de vista cómo también en el colectivo LGTB acabó imponiéndose la lógica de la mayoría y como, en aras de alcanzar

habría que situar el movimiento y la teoría «queer» que, precisamente, parte del rechazo de las etiquetas de género, de las identidades cerradas y estáticas y apuesta por una visión «performativa» de la afectividad y la sexualidad. BUTLER, J. Deshacer el género. Barcelona, Paidós, 2010, pág. 13.

35 Sobre las leyes autonómicas reguladoras de las parejas de hecho véanse CAMARERO SUÁREZ, V. Las uniones no matrimoniales en el Derecho español y comparado. Valencia, Tirant lo Blanch, 2005; y PÉREZ VILLALOBOS, M. ${ }^{a}$ C. Las leyes autonómicas reguladoras de las parejas de becho. Cizur Menor (Navarra), Thompson- Civitas, 2008.

36 En este sentido, podemos afirmar que «la aprobación del matrimonio homosexual representa un ejemplo de una política pública aprobada por un partido necesitado de redefinir el proyecto político y que ha encontrado en el movimiento gay un aliado dispuesto a ofrecer justo lo que era necesario en ese momento». CALVO, K. «Matrimonio homosexual en España. En busca de explicaciones para una nueva política», Orientaciones. Núm. 10, 2005, pág. 25. 
una conquista jurídica, se sacrificaron posiciones que apenas si tuvieron relevancia en el debate público sobre la cuestión. Desde el año 1997 la reivindicación del matrimonio se había convertido en eje de la lucha política de la Federación Estatal de Lesbianas, Gays, Transexuales y Bisexuales y fue este grupo el que actuó como interlocutor a lo largo de las negociaciones. Otros colectivos, que mantuvieron posiciones diversas, como la Fundación Triángulo o el CRECUL (Colectivo Reivindicativo y Cultural de Lesbianas) que preferían una ley de parejas de hecho, apenas si fueron visibles.

Cabe destacar cómo las principales críticas procedieron de colectivos de lesbianas, para los cuales la cuestión del matrimonio tenía «cara de varón» ${ }^{37}$. Dichos colectivos pusieron de manifiesto cómo el reconocimiento de las lesbianas como madres y esposas no conllevaba grandes cambios en los papeles asignados, sino que por el contrario se mantenían los valores dominantes y la heterosexualidad y la homosexualidad masculina marcaban las pautas. De esta manera, de poco servía el reconocimiento del matrimonio para acabar con la «discriminación múltiple» que sufren las mujeres lesbianas.

Estos interrogantes nos sitúan frente al análisis que en estos años de intensa lucha política en torno al matrimonio se nos ha hurtado. Es decir, la cuestión principal desde el punto de vista de los derechos LGTB debería enfocarse en torno a si la reforma del Código Civil ha contribuido a superar los obstáculos que tradicionalmente han tenido para desarrollar sus proyectos vitales, si el acceso al matrimonio ha supuesto y en qué medida un factor decisivo para «el libre desarrollo de su personalidad».

\subsection{Los efectos «normalizadores» del matrimonio}

Debemos recordar que la Modernidad se articuló sobre la división entre el espacio público y el privado, y sobre la consiguiente división de roles y funciones: el espacio masculino de la ciudadanía y los derechos frente al doméstico de las mujeres y los cuidados. Esa división se organizó jurídicamente a través del Derecho Civil y, en concreto, a través de una muy específica concepción del matrimonio basada en la autoridad del marido y la sumisión de la mujer. De esta manera, y como bien ha denunciado el feminismo, el contrato social estaba precedido por otro pacto de tipo sexual, mediante el cual quedaba marcada la

37 PLATERO MÉNDEZ, R. «¿Invisibiliza el matrimonio homosexual a las lesbianas? Una crítica feminista sobre la construcción y representación del matrimonio homosexual en España», Orientaciones. Núm. 10, segundo semestre 2005, pág. 111. 
diferenciación jerárquica entre hombres y mujeres ${ }^{38}$. Ello implicaba la configuración del espacio público de acuerdo con una «representación masculina y heterosexual de la humanidad del ser humano» ${ }^{39}$. Lo masculino-heterosexual se identifica con lo universal, con «lo normal», además de con «lo valioso». El referente, incluso para el mundo jurídico, será el hombre heterosexual, productor, padre de familia, pieza clave en el engranaje económico. En esta estructura el homosexual quedará expulsado tanto del ámbito público como del privado. En ningún tendrá un papel que cumplir. Su propia opción afectivo-sexual suponía un desafío a «las reglas del juego». De ahí, en el mejor de los casos, su condena a la invisibilidad y, en otros muchos, incluso su persecución penal. Como otras minorías, quedaron en las fronteras. Esta situación de invisibilidad fue aún mayor en el caso de las lesbianas. Ni siquiera «existieron» para las normas que perseguían los actos homosexuales, ya que éstas se referían siempre a los varones.

La familia es una construcción sociopolítica, pieza esencial en el orden burgués e instrumento del Estado para controlar la sexualidad y el deseo. La familia matrimonial responde, pues, a la moral propia de una clase social que la utiliza al servicio de sus intereses. Así, «como la buena marcha de los negocios, el matrimonio es un signo de triunfo, estabilidad y rentabilidad» ${ }^{40}$. La institución familiar ha sido y es «no sólo el pilar de una cultura basada en la naturalización binaria y dicotómica de las relaciones sexuales destinadas a la reproducción, pero también en el punto de apoyo lingüístico y metadiscursivo de cuyas entrañas emanaba la legitimación de los discursos punitivos al encuentro de los crímenes contra natura» ${ }^{41}$.

Ese modelo ha sido además potenciado en los diferentes ámbitos de socialización del individuo, lo que ha favorecido la construcción de la realidad social de acuerdo con la división binaria de géneros y la heterosexualidad obligatoria. En consecuencia, la familia matrimonial ha sido es el espacio privilegiado para que el patriarcado afianzara sus raíces y se perpetuara a través de una determinada concepción de la masculinidad y la feminidad. El «contrato sexual» ha sentado las bases no sólo de una determinada configuración del ámbito privado, sino también de lo público, es decir, del ejercicio de la ciudadanía. Ya lo expresó con rotundidad Rousseau en su Emilio o De la Educación, donde quedaron

38 Un contrato sexual mediante el cual los hombres controlan y se apropian de «las capacidades específicas o poderes humanos de los que están dotadas las mujeres como seres socio-sexuales». JÓNASDÓTTIR, A. El poder del amor. ¿Le importa el sexo a la democracia? Madrid, Cátedra, 1993, pág. 126.

39 VÉLEZ-PELLEGRINI, L. Minorías sexuales..., cit., pág. 50.

${ }^{40}$ SÁNCHEZ MARTÍNEZ, M. ${ }^{a}$ O. Igualdad sexual y diversidad familiar..., cit., pág. 21.

41 VÉLEZ-PELLEGRINI, L. Minorías sexuales..., cit., pág. 273. 
dibujados con precisión los patrones a los que debían ajustarse Emilio y Sofía, y donde quedaba además muy claro que son «el buen hijo, el buen marido y el buen padre quienes hacen al buen ciudadano». De esta manera, podemos afirmar con Daniel Borrillo, que «hombres y mujeres establecen un comercio sexual organizado alrededor de un orden jerárquico y con finalidad reproductiva: la heterosexualidad $»^{42}$. Y lo hacen con una posición diferenciada: «Mientras que el varón puede desarrollar su propia individualidad fuera del ámbito familiar, a la mujer le está vedada tal posibilidad porque su único destino es la familia» ${ }^{43}$.

El matrimonio ha supuesto siempre una garantía de orden y estabilidad. Su misma consideración como «garantía institucional» revela ese carácter en la medida que se pretende hacer de él una estructura rígida, considerada esencial para el funcionamiento de la sociedad y protegida frente a cambios que puedan llegar a «desnaturalizarla». La conexión matrimonio-orden conlleva a su vez, la exclusión o, en el mejor de los casos, la menor valoración de otras opciones afectivas, sexuales o de convivencia ${ }^{44}$. Basta en ese sentido con recordar la larga historia de persecución de la homosexualidad como opción «no natural», «desordenada» o peligrosa para el mantenimiento del orden público ${ }^{45}$. En una sorprendente línea de continuidad con esos discursos comprobamos cómo incluso en las posiciones defensoras del matrimonio entre personas del mismo sexo sigue latiendo la percepción del mismo como garantía de «orden» y, en paralelo, de los homosexuales y lesbianas como individuos a los que hay que reconducir. Véanse en este sentido las palabras del mismo presidente del gobierno José Luis Rodríguez Zapatero en la defensa del matrimonio gay en el Congreso de los Diputados: «Señorías, no hay agresión ninguna al matrimonio ni a la familia en la posi-

42 BORRILLO, D. «Le sexe et le droit: de la logique binaire des genres et la matrice hétérosexuelle de la loi», MERITUM, 2010, 5 (2), pp. 257-288 (copia mecanografiada facilitada por el autor).

43 SÁNCHEZ MARTÍNEZ, M. ${ }^{a}$ O. Igualdad sexual y diversidad familiar..., cit., pág. 44.

44 Algo que se pone de manifiesto en el ordenamiento jurídico con la mayor sanción que suponen determinados actos cuando son realizados por homosexuales. Así por ejemplo el Código Penal de la dictadura de Primo de Rivera, promulgado en 1928 y en vigor hasta 1932, distinguió por primera vez entre el delito sexual cometido por heterosexuales y homosexuales. En el segundo caso, el castigo era mayor.

45 En este sentido cabe recordar como la Ley de Vagos y Maleantes de 1933 estableció la idea de «estado peligroso», que si bien parecía responder a una formulación abierta y progresista, se utilizó para reprimir de manera azarosa. MIRA, A. De Sodoma a Chueca. Una historia cultural de la homosexualidad en la España del siglo XX. Madrid, Egales, 2007, pág. 185. Una ley que sería reformada en 1954 para castigar con mayor dureza los comportamientos homosexuales hasta que en 1970 se aprueba la Ley de Peligrosidad y Rehabilitación Social, cuyo mismo título contiene todo un programa heteronormativo: los homosexuales eran considerados como un peligro para la sociedad. 
bilidad de que dos personas del mismo sexo se casen. Más bien al contrario, lo que hay es cauce para realizar la pretensión que tienen esas personas de ordenar sus vidas con arreglo a las normas y exigencias del matrimonio y de la familia» (Diario de Sesiones, Congreso de los Diputados, 30 de junio de 2005) ${ }^{46}$.

Esta concepción política del matrimonio y la familia subrayó la concepción del amor no tanto como proyección de las necesidades afectivas y sexuales del individuo —en definitiva, como una expresión más de lo que en términos jurídico-constitucionales denominamos «libre desarrollo de la personalidad»— sino como «fuerza» mediante la cual se ensamblan dos partes llamadas a completarse: la masculina y la femenina. Es decir, la concepción del «amor romántico» reforzó las pautas culturales y emocionales del patriarcado y, de manera muy especial, la heterosexualidad como opción «natural»o «normal», en cuanto que suponía el deseo y la atracción de los dos opuestos: el masculino y el femenino, necesitados por la sociedad necesitaba para mantener su orden y, sobre todo, para garantizar su continuidad ${ }^{47}$. Todo ello acompañado, obviamente, de justificaciones religiosas o morales, así como de instrumentos que durante siglos fomentaron la socialización en dichos parámetros ${ }^{48}$.

No podemos negar que a lo largo del siglo XX el matrimonio, y con él la vida familiar, se fue progresivamente democratizando gracias a las reivindicaciones de las mujeres que consiguieron convertirlo en un contrato de iguales ${ }^{49}$.

46 PASCALE, E. y SAIZ, V. «Debate público acreca del matrimonio», Orientaciones. Revista de Homosexualidades. Núm. 10, 2. ${ }^{\circ}$ semestre de 2005, pág. 87.

47 El género permite construir «la ideología de la complementariedad»: «Los ideales sexuales funcionan de tal manera que permiten la búsqueda de la identificación subjetiva y la complementariedad «objetiva»: la fragilidad femenina se acomoda con la solidez masculina y la propensión doméstica de la mujer con la capacidad de realizar proyectos propia de los hombres. El matrimonio aparece como el teatro en el que se juegan los roles de género...» BORRILLO, D. «Le sexe et le droit...», cit..

48 De ahí que podamos afirmar que «el amor romántico es un arma de control social cuya base es el matrimonio, y cuyo fin es la perpetuación de la familia nuclear tradicional, el sistema patriarcal y el capitalismo democrático» HERRERA GÓMEZ, C. La construcción sociocultural del amor romántico. Madrid, Fundamentos. 2010, pág. 20. Esa concepción del amor, y con él del matrimonio y la familia, ha contribuido a mantener durante siglos las servidumbres de las mujeres. Hasta el punto que se ha llegado a afirmar que «el amor es el opio de las mujeres... (para ellas) la única trascendencia posible en una sociedad secularizada es la del amor... el amor como opio, como sueño, como magia, como fantasía de la vida, como lo maravilloso en la vida». SUBIRATS, M. en CASTELL, M. y SUBIRATS, M. Mujeres y hombres: ¿un amor imposible? Madrid, Alianza, 2007, pág. 262.

${ }_{49}$ Como bien explica M. ${ }^{a} \mathrm{O}$. Sánchez, las familias han de articularse en torno a «la negociación de los desacuerdos. Unos desacuerdos que aumentan al mismo tiempo que se amplían las experiencias de la vida de una mujer, cuya actividad cotidiana no queda ya reducida al ámbito del 
De ahí que, por ejemplo, las primeras reformas significativas que se hicieron en nuestro ordenamiento jurídico tras el fin de la dictadura franquista fueran las relacionadas con el Derecho de Familia. Y de ahí también que en aquellos contextos aún dominado por culturas patriarcales el matrimonio y la familia sigan respondiendo a códigos poco respetuosos con la dignidad y libertad de las mujeres. Baste al respecto con examinar los países que formularon reservas a los apartados relativos al Derecho de Familia al ratificar la Convención de Naciones Unidas sobre la eliminación de todas las formas de discriminación contra la mujer de 1979.

A pesar de todos los cambios operados en su régimen jurídico, es evidente que el matrimonio continúa siendo en el «imaginario colectivo» un contrato que no sólo genera derechos y obligaciones sino que también otorga una suerte de estatus que confiere respetabilidad. Desde este punto de vista, el matrimonio ha aparecido ante los demás como garantía de estabilidad e incluso de rectitud desde el punto de vista moral. Durante siglos fue la única vía de desarrollo personal permitida a las mujeres mientras que a los hombres les confería un mayor peso en la vida social y venía a completar lo que se suponía era su ámbito normal de desarrollo, es decir, la vida pública ${ }^{50}$.

En paralelo, la familia continúa siendo el referente de la felicidad, de la plenitud del individuo, de la realización personal. Los medios de comunicación, la publicidad, el mercado en general, siguen usando la imagen idílica del matrimonio heterosexual como el marco casi obligatorio en el que el individuo ha de desarrollar su proyecto vital. Basta con repasar cómo por ejemplo el consumo se articula en función de un modelo familiar, o como el mismo diseño de las viviendas responde a ese modelo imperante. Es decir, «existe una presión mediática y cultural que presenta al amor y la pareja como la institución que colmará las aspiraciones de felicidad individuales a través de lo que en la cultura occidental se define como la «media naranja», es decir, una interpretación de la

hogar. Es preciso armonizar dos vidas distintas con sus propias dinámicas, expectativas, opciones, decisiones e inconvenientes que dependen de la propia personalidad y no de roles sexuales (...) El equilibrio y la armonía familiar exigen ahora un intercambio entre semejantes, presidido por la igualdad y reciprocidad, lo cual exige un esfuerzo permanente, un orden consensuado y no definitivo, abierto siempre a nuevos acuerdos que permitan mantener aquella armonía ante el cambio de circunstancias de cualquiera de ellos». Igualdad sexual y diversidad familiar, cit., págs. 47-48.

50 «El matrimonio heterosexual es, así, una institución social que canaliza la sexualidad humana hacia la fertilidad, ya que la monogamia continuada es la que maximiza con frecuencia de coitos en cada ciclo y, en ausencia de controles limitativos de la fertilidad, las probabilidades de fecundación. Existe entonces una relación clara entre la función económica y social (división sexual del trabajo), una institución social (matrimonio heterosexual) y una función biológica (sexualidad procreadora)» PICHARDO, J.I. Entender la diversidad familiar, cit., pág. 2009. 
idea platónica de que existe una única persona que complementa de forma casi completa la vida personal. Lo realmente paradójico es que el reconocimiento del derecho al matrimonio a gays y lesbianas ha venido a subrayar ese imaginario ${ }^{51}$. En este sentido, baste con recordar como las imágenes mediáticas de bodas de gays y lesbianas nos siguen remitiendo a un ritual y hasta a una indumentaria que suponen la interiorización de una práctica social consolidada. De esta manera, comprobamos como la boda sigue operando como ritual social, cargado de simbolismo y de toda la carga conservadora que tienen los ritos. Se trata de una celebración colectiva, en la que la sociedad «bendice» nuevas unidades de producción y reproducción.

La pervivencia de este orden cultural y simbólico, del que ahora también participan gays y lesbianas, puede provocar una doble consecuencia ${ }^{52}$ : 1.a) Para escapar de una posición subalterna, habrá muchos homosexuales que, aunque no lo tuviesen presente en sus proyectos vitales, acaben optando por el matrimonio como una vía hacia el respeto social y el acceso a derechos y a la ciudadanía ${ }^{3}$. 2. $\left.{ }^{a}\right)$ Aquellos homosexuales que prefieran entrar en ese modelo, pueden considerarse peor considerados de lo que lo estaban anteriormente y pueden sentirse presionados para encajar en ese nuevo modelo de familia ${ }^{54}$.

De esta manera se alcanza el efecto de «normalización», con todas las connotaciones negativas que implica este término. Normalizar implica convertir algo en «normal»y, en el tema que nos ocupa, conlleva el riesgo de querer diferenciar el patrón de normalidad — la heterosexualidad — frene a las «anormalidades» que representan otras opciones. Ello, a su vez, nos llevaría al «perverso» debate sobre la protección de las minorías ya que, en este caso, el factor meramente cuantitativo puede provocar una desigualdad de derechos. En definitiva, todos en determinadas situaciones y perspectivas acabamos formando parte de

51 «Las imágenes mediáticas de parejas y bodas gays y lesbianas rodeadas de ritos y provistas de una indumentaria que no dejaba de invocar identidades y roles de género, siguen hoy percibidas, no como una transgresión de la norma (mediante una supuesta interpretación de los sacramentos del matrimonio y el ceremonial que lo circunscribe), sino como la interiorización pasiva de la práctica social». VÉLEZ-PELLEGRINI, L. Minorías sexuales..., cit., pág. 323.

52 PICHARDO, J. I. Entender la diversidad familiar, cit., pág. 326.

53 En este sentido cabe señalar como la reforma de 2005 ha provocado que en los últimos años aumenten los matrimonios con cónyuges extranjeros, ya que supone una vía rápida de acceso a la residencia. Según los datos del INE, en 2009 hubo 3.412 bodas entre personas del mismo sexo, de las que 1.285 se celebraron entre cónyuges de diferentes nacionalidades. En el caso de las heterosexuales el porcentaje fue mucho menor: 29.981 de las 172.540 celebradas.

54 Estas probables situaciones nos confirman que «la libertad para elegir un modelo de convivencia depende en gran medida de la protección jurídica de que goce cada uno de ellos». SÁNCHEZ MARTÍNEZ, M. ${ }^{a}$ O. Igualdad sexual y diversidad familiar, cit., pág. 132. 
una «minoría» frente a una «mayoría» con la que no compartimos determinados rasgos. Desde una perspectiva democrática, y en la que por tanto igualdad y pluralismo deben ir la mano, lo «normal» debe ser «lo diverso» y es la garantía de esa diversidad el papel que debe cumplir un sistema de derechos y libertades. Por ello, el objetivo del sistema debería ser no normalizar sino reconocer. Estos argumentos hacen realmente sorprendente que desde el movimiento LGTB, o al menos desde ciertos sectores del mismo, se ponga tanto el acento en mantener el imaginario «heteronormativo».

Entiendo que la lucha por el matrimonio se haya convertido en bandera de un movimiento reivindicativo de igualdad de derechos, pero pienso que, a pesar del indudable avance que representa, corre un doble riesgo: $\left.1 .^{\circ}\right)$ reducir la diversidad afectivo-sexual a las pautas heteronormativas y patriarcales; $2 .^{\circ}$ ) concentrar la reivindicación de derechos en una cuestión singular cuya consecución puede provocar una ficción de igualdad, en la medida en que supone situar en un lugar secundario otros retos.

No deberíamos olvidar que el verdadero reto es transformar una sociedad que continúa siendo homófoba - lo cual significa que es necesario cambiar el orden patriarcal que la sustenta- - y, para ello, habría que incidir especialmente en las políticas educativas y en todos los procesos socializadores del individuo. El patriarcado, del que es una característica singular la homofobia, es, por encima de todo, una cultura, con proyecciones en lo político, en lo jurídico y en todos los ámbitos sociales. Indudablemente el reconocimiento del derecho al matrimonio entre personas del mismo sexo puede ayudar a transformar patrones culturales, pero al mismo tiempo no podemos obviar que dicha opción asimilacionista supone insistir más en la igualdad como identidad que como reconocimiento de las diferencias.

\section{EL LIBRE DESARROLLO DE LA AFECTIVIDAD Y LA SEXUALIDAD COMO PRESUPUESTO DE LA DIVERSIDAD FAMILIAR}

Todos esos interrogantes nos ponen de manifiesto, como mínimo, las dudas que genera no tanto la constitucionalidad del matrimonio entre personas del mismo sexo sino su efectividad en el largo proceso de conquista de derechos por parte de colectivos que, durante siglos, han sido discriminados e incluso perseguidos por el ordenamiento jurídico. En este sentido, el reconocimiento del matrimonio habría de interpretarse como una conquista evidente, pero no como la definitiva.El gran reto de los sistemas constitucionales es el reconocimiento de la diversidad no sólo de lo modelos de convivencia sino también de las «ma- 
neras» en que nos construimos como hombres o como mujeres. Este objetivo incide de manera directa en el mismo concepto de «ciudadanía», en cuanto que nuestra identidad es la base desde la que ejercemos los derechos y libertades, tanto en el ámbito público como en el privado.

Desde esta perspectiva, la protección de la orientación sexual y de la identidad de género ha de superar los límites estrechos de la prohibición de discriminación, y por supuesto de su anclaje exclusivo en la vida privada, y ha de contemplarse desde los presupuestos de nuestro orden político: la dignidad y el libre desarrollo de la personalidad. Es preciso avanzar en la consideración del desarrollo sexual y afectivo como una faceta esencial de la personalidad y que, por tanto, está ligado íntimamente a la dignidad del ser humano y a la «igualdad de reconocimiento». Es decir, la normalización jurídica y social de las diversas opciones afectivas y sexuales exige su inserción en el ámbito público, su protección como una dimensión de la personalidad a través del principio de igualdad así como su proyección en diversos ámbitos que, aunque conectados de manera estrecha con la vida privada, tienen evidentes repercusiones en otros espacios ${ }^{55}$.

Ante la ausencia de proclamación constitucional expresa, estamos obligados a deducir tal derecho de la conjunción de diversos principios constitucionales que nos ofrecen un marco jurídico protector. Junto a la igualdad formal, y la consiguiente prohibición de discriminación, es necesario tener presente la cláusula de igualdad material del art. 9.2 CE. En relación a ésta, es preciso subrayar la dimensión colectiva o de grupo que también puede suponer la orientación sexual. A pesar de las dificultades que puede suponer la definición de un grupo, y sobre todos de los rasgos o elementos que determinan la pertenencia al mismo, en el caso de LGTB sí que podemos determinar un factor de cohesión que es la histórica discriminación y su lucha por tener una voz propia en el espacio democrático. De esta manera se conectan además las dos proyecciones que podemos deducir del art. 9.2 CE. No se trata sólo de que sean necesarias actuaciones públicas para favorecer una igualdad real, sino también para favorecer la participación de todos los ciudadanos y de todas las ciudadanas en la vida política, económica, cultural y social. Ello supone favorecer el empoderamiento de todos los

55 Un reto que habría resultado jurídicamente más fácil si nuestra Constitución hubiera recogido el contenido del voto particular al art. 27 propuesto por el Grupo Socialista del Congreso en el proceso constituyente «Toda persona tiene derecho al desarrollo de su afectividad y sexualidad, a contraer matrimonio, a crear en libertad relaciones estables de familia y a decidir libremente los hijos que desean tener, a cuyo fin tiene derecho a acceder a la información necesaria y a los medios que permita su ejercicio». SAINZ DE MORENO, F. (edición preparada por) Constitución Española. Trabajos parlamentarios. Tomo I. Madrid, Publicaciones de las Cortes Generales, 1989, págs. 11,42 y 52 . 
hombres y todas las mujeres, desde la diversidad de sus opciones sexuales y afectivas, con pleno reconocimiento de su voz, de sus diferencias, de su identidad.

Ambos factores, igualdad y participación, pueden entenderse como proyecciones de la «identidad» del individuo o, dicho de otra manera, como herramientas esenciales para el «libre desarrollo de la personalidad» (art. 10.1 CE). Es en este concepto, íntimamente ligado al de dignidad, donde hallamos la clave constitucional para entender la afectividad y la sexualidad como elementos de la identidad individual y, por tanto, como derechos que merecen protección jurídica y reconocimiento social. Unos derechos que forman parte de la «integridad moral» del individuo (art. $15 \mathrm{CE}$ ) y que, por tanto, han de situarse en el nivel más garantista de cualquier sistema de libertades, tal y como se desprende del tercero de los Principios de Yogyakarta ${ }^{56}$ :

«Todo ser humano tiene derecho, en todas partes, al reconocimiento de su personalidad jurídica. Las personas en toda su diversidad de orientaciones sexuales o identidades de género disfrutarán de capacidad jurídica en todos los aspectos de la vida. La orientación sexual o la identidad de género que cada persona defina para sí, es esencial para su personalidad y constituye uno de los aspectos fundamentales de la autodeterminación, su dignidad y su libertad».

La identidad, por tanto, habría de considerarse como el armazón jurídicoconstitucional a partir del cual se proyectan y desarrollan todos los derechos que posibilitan la autonomía del individuo y, en definitivas, sus capacidades para diseñar y ejecutar un plan de vida ${ }^{57}$. Esta concepción de la identidad puede ser reconducida, en clave jurídico-constitucional, a una libertad de la que tradicionalmente se han ofrecido lecturas parciales. Me refiero a la libertad de conciencia, no expresamente recogida en la Constitución de 1978, pero sí deducible del

${ }^{56}$ Los Principios de Yogyakarta fueron elaborados a petición de Louise Arbour, ex Alto Comisionado de las Naciones Unidas para los Derechos Humanos (2004-2008) y se redactaron en noviembre de 2006 en la ciudad indonesia de Yogyakarta por un grupo de 29 expertos en Derechos Humanos y derecho internacional de varios países. Su presentación tuvo lugar el 26 de marzo de 2007 en el Consejo de Derechos Humanos de la ONU y posteriormente fue ratificado por la Comisión Internacional de Juristas. Se trata de un documento que contiene una serie de principios legales cuyo fin es la aplicación de las normas de derecho internacional de derechos humanos en relación a la orientación sexual y la identidad de género. El texto marca los estándares básicos para que las Naciones Unidas y los Estados avancen para garantizar la protección de los derechos humanos a las personas LGBT.

57 Esta formulación omnicomprensiva, y transversal, es la que late en la proclamación que hace al art. 26.1 de la Constitución portuguesa: «Se reconoce a todos el derecho a la identidad personal, al desarrollo de la personalidad, a la capacidad civil, a la ciudadanía, al buen nombre y reputación, a la imagen, a la palabra, a la reserva de la intromisión de la vida privada y familiar y a la protección familiar contra cualquier forma de discriminación». 
art. 16 CE. La libertad de conciencia, que supone «no solamente el derecho a formar libremente la propia conciencia sino también a obrar de manera conforme a los imperativos de la misma» (STC 15/1982, FJ 6. ${ }^{\circ}$ ), es el «tronco» que permite a cada individuo ser su propio «legislador» y no sólo en ámbitos que de manera más estricta tienen que ver con el pensamiento, sino también con las opciones más personales e íntimas de su existencia, entre las que sin duda se encuentran la afectividad y la sexualidad. En cuanto que lo que se protege es «un espacio de autodeterminación individual» (STC 177/1996, FJ 9. ${ }^{\circ}$ ), con ella estamos garantizando todas las dimensiones —espirituales, religiosas, éticas, políticas, afectivas, sexuales - que configuran a cada hombre y a cada mujer como un ser único. Y, de la misma manera que el TC ha reiterado que la libertad de conciencia tiene una evidente dimensión externa, también los aspectos afectivos y sexuales del individuo tienen una proyección social que obliga a protegerlos desde la perspectiva de la igualdad. Tanto es así que podríamos concluir que la mayor parte de los derechos fundamentales reconocidos por nuestro ordenamiento — desde los políticos a los más personales como los que tienen que ver con la familia ${ }^{58}$ — son, nada más y nada menos, que concreciones de ese «claustro íntimo», de «espacio de autodeterminación individual», que se proyectan en la vida social. Desde esta perspectiva, y como vengo apuntando, la protección de la identidad está ligada al «reconocimiento», en cuanto que aquélla se define y se materializa de manera principal en nuestras relaciones con los demás. Está pues vinculada con la estima personal y, a su vez, con la que generamos a nuestro alrededor. De ahí que, desde esta dimensión, la identidad se deba beneficiar también de las garantías que proporcionan derechos como el honor, la intimidad o la propia imagen (art. $18 \mathrm{CE}$ ).

La afectividad y la sexualidad forman parte esencial de la personalidad del individuo y, como tales, se hallan en las raíces dan sentido al sistema constitucional. Es decir, ambas son piezas sin las que no es posible construir la dignidad del individuo — «La dignidad es un valor espiritual y moral inherente a la persona, que se manifiesta singularmente en la autodeterminación consciente y responsable de la propia vida y que lleva consigo la pretensión al respeto por parte de los demás» (STC 53/1985, FJ8 . .) — y sin las que no es posible desplegar todas sus potencialidades y capacidades, es decir, sin las que difícilmente podríamos hablar del libre desarrollo de la personalidad (art. 10. $1 \mathrm{CE}$ ).

58 Esta perspectiva es la que nos ofrecería los argumentos más sólidos para reconocer la constitucionalidad del matrimonio entre personas del mismo sexo, así como para revisar determinados conceptos del Derecho de Familia — tales como la paternidad o la filiación_- de acuerdo con la debida protección de la identidad individual. 


\section{AUTONOMÍA Y DIVERSIDAD: LOS EJES DE UNA NUEVA CONCEPCIÓN DEL DERECHO DE FAMILIA}

Todo ello nos lleva necesariamente a una concepción dinámica, dúctil, de la familia y de los diferentes modelos de convivencia que el individuo elija como cauce para desarrollarse personal y afectivamente. Esa diversidad implica pues la necesidad de conjugar en plural el término «familia», en el sentido de que son muchos y variados los modelos que, desde la libre voluntad y el consentimiento, pueden generarse. La misma ubicación constitucional de la protección de la familia en un artículo distinto al del matrimonio nos da la pauta para entender que no necesariamente tiene que ser la vinculada al matrimonio y que, por tanto, hay un amplio margen para que el legislador defina a quiénes extiende la protección social, económica y jurídica a que se refiere dicho artículo ${ }^{59}$. Una proclamación en la que lo único que parece incuestionable es la protección de los hijos y de la maternidad, así como el deber de los padres y las madres de prestar asistencia de todo orden a los hijos ${ }^{60}$.

En este debate es central la revisión de las relaciones entre los espacios público y privado, teniendo en cuenta que históricamente los colectivos no heterosexuales han sido excluidos de ambos. La clave se halla pues en la creación

59 La STC 198/2012 insiste en este argumento para rechazar la vulneración del art. 39 CE alegada en el recurso de inconstitucionalidad y reitera la doctrina consistente en considerar matrimonio y familia como «dos bienes constitucionales diferentes».

${ }^{60}$ Así lo expresan con rotundidad los citados Principios de Yogyakarta. Tras reconocer el derecho de toda persona a formar una familia, con independencia de su orientación sexual o identidad de género, se afirma que «existen diversas configuraciones de familias» (principio 24). Una afirmación que puede parecer obvia pero que es necesario reafirmar incluso en contextos democráticos avanzados como el nuestro. Por ello son tan importantes las prescripciones que establece el principio 24. Entre otras cuestiones se pide a los Estados que adopten todas las medidas legislativas, administrativas y de otra índole que sean necesarias, a fin de asegurar el derecho a formar una familia, incluso a través del acceso a la adopción o a la reproducción asistida (incluyendo la inseminación por donante), sin discriminación por motivos de orientación sexual o identidad de género», así como que velen por que las leyes y políticas reconozcan la diversidad de formas de familias, incluidas aquellas que no son definidas por descendencia o matrimonio, así como por que se adopten todas las medidas legislativas, administrativas y de otra índole necesarias para asegurar que ninguna familia sea sometida a discriminación basada en la orientación sexual o identidad de género de cualquiera de sus integrantes, incluso en lo que respecta al bienestar social y otros beneficios relacionados con la familia, al empleo y la inmigración. En todo caso, estas proclamaciones habría que entenderlas con todos los matices que conlleva la misma idea de «maternidad» y «paternidad» en el siglo XXI. Por otra parte, la proclamación del apartado $3 .^{\circ}$, si hacemos una lectura literal del término "padres», dibuja un modelo de padre excesivamente deudor de la estructura patriarcal en la que él era el «proveedor» y la mujer la «reproductora». Por ello sería más ajustado que en su redacción apareciera el término «progenitores» o bien «padres» $\mathrm{y}$ «madres». 
de las condiciones que permitan a cualquier individuo, cualquiera que sea su orientación sexual o afectiva, puede desarrollar libremente su personalidad. Ello pasa necesariamente por los dos ámbitos, el público y el privado, así como por las relaciones que se establecen entre ambos. De ahí que sea necesario avanzar en el reconocimiento público de los colectivos no heterosexuales, de manera que se borren la diferenciación entre «mayoría» y «minorías». Este objetivo implica el acceso en condiciones de igualdad al espacio público, acabando de una vez por todas con la dinámica del «gueto» como espacio de «tolerancia» que, en el fondo, encierra una sutil discriminación: la que sigue mostrando quiénes son la mayoría y quiénes la minoría «tolerada». Por otra parte, y en relación más estrecha con la vida íntima pero también con evidentes repercusiones públicas, es necesario que cualquier individuo pueda desarrollar en libertad y en igualdad de condiciones su «proyecto vital», del que forma parte su vida afectiva y sexual.

Como la identidad no es algo estático y cerrado, sino más bien un proceso, también deberíamos entender así sus diversas proyecciones, muy en especial las que tienen que ver con la afectividad y la sexualidad ${ }^{61}$. Si entendemos que la lógica consecuencia del reconocimiento de la igual dignidad de todos y de todas es la asunción de la capacidad del individuo para «construir» su vida, es esta perspectiva la que nos debe servir para la protección de las diversas fórmulas de convivencia posibles, partiendo del reconocimiento de la capacidad personal para autorregular la vida privada y familiar ${ }^{62}$.

En este sentido, hay que tener presente un dato que pareció olvidarse en el debate en torno al reconocimiento del derecho al matrimonio, tal vez porque primó la urgencia de la conquista jurídica más que la necesaria protección de la diversidad. Me refiero a que tradicionalmente, y debido en parte a la exclusión sufrida, en el mundo homosexual se han vivido otras experiencias de convivencia, menos rígidas que el matrimonio y basadas más en la negociación y en el respeto de la autonomía de cada uno de los integrantes de la pareja ${ }^{63}$. El con-

61 De esta manera, hay quienes consideran el parentesco como un conjunto o set de elementos, «autoconscientemente construido a partir de una multiplicidad de posibles elementos y piezas», de forma que la familia acaba siendo más con un conjunto de prácticas sociales que una institución. PICHARDO, J. I. Entender la diversidad familiar, cit. Pág. 58.

62 Lentamente, pero sin pausa, el ordenamiento jurídico va introduciendo rupturas en el triángulo matrimonio-familia-procreación. Valga como ejemplo la reciente sentencia del Tribunal Constitucional 41/2013, de 14 de febrero, mediante la cual se ha considerado contraria al art. 14 CE la exigencia de la Ley 40/2007 de Seguridad Social consistente en condicionar el acceso a la pensión de viudedad a que la pareja de hecho, heterosexual u homosexual, hubiera tenido hijos en común.

63 El propio desarrollo «conflictivo» de la personalidad sufrido por las personas del colectivo LGTB les ha llevado a buscar alternativas más ricas, basadas más en la «lealtad» que en la «fidelidad» y en las que ha sido un factor decisivo el mantenimiento de la autonomía que, en la mayoría 
cepto de «elección» es clave en la definición de estas alternativas, así como la creación de redes de apoyo, informales, flexibles y en el que en ocasiones priman más los lazos de amistas que los familiares ${ }^{64}$. Esas múltiples experiencias enlazan a su vez con la reclamación cada vez más mayoritaria entre las parejas de ser «legisladores de su situación personal» ${ }^{65}$.

En este proceso de revisión del concepto tradicional de «familia», deberíamos incorporar como criterio definidor de la misma no sólo la convivencia y las relaciones de afectividad, sino también su capacidad para generar lo que podríamos denominar «relaciones de cuidado». De esta manera, la convivencia, la solidaridad, la creación de vínculos afectivos y cuidadores no necesariamente condicionados por la sangre, deberían convertirse en factores esenciales de las «nuevas familias». Este criterio, por ejemplo, debería ser el determinante a la hora de regular la adopción, entendiendo que la protección del menor está vinculada precisamente con la creación de unas condiciones de bienestar adecuadas, así como de unos vínculos afectivos y de cuidado que garanticen su pleno desarrollo de la personalidad ${ }^{66}$. Todo ello junto a la consolidación de estructuras más horizontales, en las que se difuminen los roles tradicionales de género y donde el poder se halle más descentralizado y sometido a una permanente negociación entre los proyectos personales de los miembros de la pareja ${ }^{67}$. En este sentido se ha llegado a hablar de «familia posfamiliar» ${ }^{68}$, concepto con el que trata de reflejarse el conjunto de vinculaciones transversales y la compleja red de relaciones que conforman las nuevas familias ${ }^{69}$. De todas ellas tal vez la más

de los casos, ha costado tanto esfuerzo alcanzar. De ahí que la negociación sea un elemento clave en estas parejas, así como la obvia superación de la sexualidad centrada en la procreación. PICHARDO, J. I. Entender la diversidad familiar, cit., pág. 152. De la misma manera, «al no existir una jerarquía de género, las uniones homosexuales ofrecen un tipo de relación más igualitario. Asimismo, la ausencia histórica de prescripciones sociales y la falta de modelos de referencia han permitido a estas parejas mayor creatividad a la hora de administrar los roles conyugales». BORRILLO, D. «El pacto civil de solidaridad...», cit., pág. 40.

${ }^{64}$ PICHARDO, J. I. Entender la diversidad familiar..., cit. Págs. 300-301.

${ }^{65}$ SÁNCHEZ MARTÍNEZ, M. ${ }^{a}$ O. Igualdad sexual y diversidad familiar..., cit., pág. 65.

${ }^{66}$ Una de las cuestiones más debatidas en torno al matrimonio igualitario ha sido la posibilidad de que dos personas del mismo sexo puedan adoptar. De hecho, éste fue uno de los motivos en los que se apoyó el recurso de inconstitucionalidad planteado por el PP, al entender que dicha vinculación chocaba con el deber de protección integral de los hijos (art. 39.2 CE). Al respecto mantiene la STC 198/2012 que en todo caso la legislación garantiza la preservación del interés del menor.

${ }^{67}$ SÁNCHEZ MARTÍNEZ, M. ${ }^{a}$ O. Igualdad sexual y diversidad familiar..., cit., pág. 33.

68 BECK-GERNSHEIM, E. La reinvención de la familia: en busca de nuevas formas de convivencia. Barcelona, Paidós, 2003, pág. 28.

69 Al mismo tiempo habría que tener presente cómo las relaciones afectivo-sexuales están progresivamente perdiendo la característica de su estabilidad o permanencia —el amor «para toda 
reseñable sea la indefinición de los límites con respecto a quién pertenece a ellas: «la paternidad o maternidad biológica, legal y social pueden no coincidir con lo que se genera una parentalidad socio-afectiva no coincidente con los vínculos biológicos o legales. Los parentescos pueden ser puramente electivos e, incluso, múltiples, se habla así de pluriparentalidad o multiparentalidad ${ }^{70}$.

El verdadero reto sería, pues, no ya sólo que el ordenamiento jurídico reconozca el matrimonio entre personas del mismo sexo, sino modificar el orden jurídico, de manera que no siga funcionando sobre la división binaria de géneros y sobre el mandato de la heterosexualidad ${ }^{71}$. Ello debería llevar a revisar conceptos

la vida»—, de forma que la realidad nos muestra cada vez con más frecuencia una «sucesión» de relaciones. De ahí las propuestas que se han llegado a realizar de regular el matrimonio o fórmulas de convivencia para períodos determinados, es decir, como un contrato temporal, en el que siempre cabría la posibilidad de ampliación del plazo en el que seguirían surtiendo efectos los derechos y obligaciones que genera. La última noticia al respecto aparecía en la prensa en noviembre de 2011: En la Asamblea del Distrito Federal de México se presentó una iniciativa de reforma del Código Civil, por parte del Partido de la Revolución Democrática, y con el objetivo de garantizar que los matrimonios tengan una vigencia mínima de dos años. De esta manera, se pretende que las parejas pudiesen renovarlo cada dos años, como si se tratara de un contrato laboral ( $A B C$, lunes 3 de octubre de 2011, p. 77).

70 SÁNCHEZ MARTÍNEZ, M. ${ }^{a}$ O. Igualdad sexual y diversidad familiar..., cit., pág. 51.

71 Debemos tener en cuenta que precisamente en relación a estas cuestiones la reforma del 2005 mantuvo diferencias entre heterosexuales y homosexuales, las cuales sobre todo continúan incidiendo en la discriminación de las lesbianas: $\left.1 .^{\circ}\right)$ No se han modificado los artículos que se refieren a la filiación (arts. 116, 117 y 118 Código Civil). Si un bebé nace en un matrimonio heterosexual automáticamente se reconoce la paternidad del cónyuge de la madre. Si lo hace en un matrimonio de dos mujeres, no se reconoce la relación de maternidad del cónyuge de la madre, sino que la otra madre se verá obligada a adoptar al bebé; $2 .^{\circ}$ ) Las parejas heterosexuales pueden adoptar conjuntamente un hijo sin tener que casarse o registrarse como pareja de hecho (Ley 21/1987, de 11 de noviembre). Las parejas homosexuales tendrían que casarse si quieren adoptar conjuntamente o, si viven en Navarra, País Vasco, Aragón o Cataluña, inscribirse como pareja de hecho; $\left.3 .^{\circ}\right)$ Mientras que una mujer podía inseminarse con semen de un banco y obtener el reconocimiento legal de paternidad directamente para su pareja varón aunque no esté casada con él, una mujer lesbiana no podría hacer lo mismo con su pareja mujer. En 2007 se introdujo una Disposición Adicional en la Ley 3/2007, de 15 de marzo, reguladora de la rectificación registral de la mención relativa al sexo de las personas, que permite que los bebés nacidos mediante técnicas de reproducción asistida de una mujer casada con otra mujer sean reconocidos legalmente como hijos o hijas de la madre no biológica, siempre que ésta muestre previamente al nacimiento su consentimiento. Con este cambio, sin embargo, queda sin resolver la situación de los hijos o las hijas concebidos/as por otras vías en el interior del matrimonio ni para los de aquellas parejas de mujeres que opten por no casarse o registrarse como parejas de hecho; $4^{\circ} .^{\circ}$ Las parejas de hombres homosexuales que utilizan la gestación subrogada en España, ya que no está permitida en nuestro país, se encuentran con el impedimento de inscribir a sus bebés en el registro civil con sus dos padres varones. Pichardo, J. I. Entender la diversidad familiar, cit., pág. 157. Con posterioridad a 
básicos del Derecho de Familia como los de «filiación» o «parentesco», de manera que se erosionara la «conexión simbólica entre la filiación, el coito genital heterosexual y el matrimonio» que «sigue operando no sólo en los imaginarios colectivos, sino también en el aparato legal y judicial» ${ }^{72}$.

Como propone Daniel Borrillo, la nueva gramática sexual debería estar determinada por la elección del individuo. En consecuencia, el Derecho Civil debería fundarse sobre el principio de autonomía de la voluntad más que sobre una supuesta «verdad» biológica ${ }^{73}$. Ello permitiría regular a la vez situaciones como las de los transexuales e intersexuales, así como erradicar la prohibición del matrimonio y de la adopción entre parejas del mismo sexo. Una vez que la referencia al sexo desapareciera de los actos del estado civil, la dualidad sexual dejaría de ser una condición sine qua non del ius connubii. De esta manera, el matrimonio encontraría su legitimidad sólo y exclusivamente en el consentimiento de los contrayentes y no en la diferencia de los sexos. Igualmente, la adopción debería también fundarse sobre la voluntad, la cual garantizaría mucho mejor que «la verdad biológica» la estabilidad de los lazos familiares. De esta manera, el ordenamiento jurídico podría ofrecer garantías más ciertas a la multiplicación de las posibilidades de acceso a la maternidad y la paternidad que se han producido en los últimos años. Así, se podría llegar incluso al reconocimiento de «coparentalidad» entre más de dos personas (por ejemplo, entre una pareja de mujeres lesbianas, en la que una de ellas sea la madre biológica, y el padre biológico que participa activamente en la crianza y cuidado del menor $)^{74}$. Muchas de las dificultades que el ordenamiento jurídico sigue ofreciendo para llevar a cabo dicho reconocimiento se eliminarían si se eliminase la presunción de paternidad y fuera siempre necesario un reconocimiento activo de la relación de filiación por las dos partes. Esto implicaría que si un bebé nace en un matrimonio, tanto la madre biológica como el esposo o la esposa de la mujer que lo engendra, tendrían que reconocer en ambos casos a ese hijo o hija

la publicación de estas reflexiones, la Dirección General de los Registros y del Notariado publicó la Instrucción de 5 de octubre de 2010 sobre régimen registral de la filiación de los nacidos mediante gestación por sustitución.

72 PICHARDO, J. I. «(Homo)sexualidad y familia: cambios y continuidades al inicio del tercer milenio», Política y Sociedad, vol. 46, núm. 1 y 2, 2009, pág. 158.

73 BORRILLO, D. «La vérité biologique contre l'homoparentalité: le statut du beau-parent ou le PaCS de la filiation», Droit et Société, núm. 72, 2009, pág. 363.

${ }^{74}$ J. I. Pichardo cita como ejemplo la decisión de un juez de Ontario (Canadá) que ha reconocido como progenitores de un niño al mismo nivel a una pareja de lesbianas (una de ellas es la madre biológica) junto con el padre biológico, un amigo de ambos que participa activamente en la crianza del menor. «(Homo)sexualidad y familia: cambios y continuidades al inicio del tercer milenio», cit., pág. 151. 
como propio/a. De esta manera se consolidaría el carácter meramente social y voluntario de la filiación ${ }^{75}$.

Junto a estas revisiones, que en buena medida suponen erosionar los cimientos de un Derecho Civil excesivamente deudor de un orden heteronormativo y poco atento a las diferencias, tal vez deberíamos plantearnos una cuestión previa. Me refiero a la concepción del matrimonio y de la familia que deriva de él como llave que garantiza el acceso a determinados derechos. Los sistemas jurídicos deberían avanzar en el sentido de la reglamentación individual de derechos - muy especialmente, los de tipo social o que implican el acceso a prestaciones públicas - y de reconocer a cada ciudadano o ciudadana la capacidad para decidir cuáles son sus relaciones relevantes. Ello sí que supondría una efectiva garantía del libre desarrollo de la afectividad y la sexualidad, por más que implicara la asunción por los ordenamientos jurídicos de la inevitable complejidad que supone el reconocimiento de las dos características del ser humano que deberían ser irrenunciables, es decir, la autonomía y, como consecuencia principal de ella, la diversidad.

Title:

RIGHT TO MARRIAGE AND FAMILY DIVERSITY

\section{Summary:}

1. The constitutionality of equal marriage. 1.1. The necessary flessible interpretation of article 32 CE. 1.2 Marriage and equal recognition. 2. The marriage as «institutional guarantie» of the patriarchate. 2.1 Heteronormativity and citizenship. 2.2. The plural voices of the LGBT movement. 2.3. The «normalizing» effects of marriage. 3. The free development of affectivity and sexuality as a point of de-

75 PICHARDO, J. I. Entender la diversidad familiar, cit., pág. 158. Como indica D. Borrillo, «todo ello obligaría a "construir un sistema internacional de derechos sexuales y reproductivos en su dimensión positiva, es decir un derecho a la sexualidad no medicalizado y un derecho a la reproducción, que permita ampliar el acceso a las técnicas de reproducción medicamente asistidas, y comprensivo de las maternidades de sustitución, al conjunto de individuos y de parejas" "La vérité biologique contre l'homoparentalité: le statut du beau-parent ou le PaCS de la filiation"», cit., pág. 369. 
parture of family diversity. 4. Autonomy and diversity: the axes of a new conception of the family law.

\title{
Palabras clave
}

Matrimonio igualitario, diversidad familiar, afectividad, sexualidad, igualdad.

\section{Key words}

Equal marriage, family diversity, affectivity, sexuality, equality.

\section{Resumen}

El reconocimiento del matrimonio entre personas del mismo sexo constituye un avance en la garantía de la dignidad de la persona y del libre desarrollo de la personalidad. Ahora bien, el matrimonio responde a un modelo de convivencia diseñado de acuerdo con los intereses y patrones de la mayoría heterosexual. Por lo tanto su extensión a gays y lesbianas tiene también un discutible efecto «normalizador». Frente a esta respuesta asimilacionista, el libre desarrollo de la afectividad y sexualidad debería convertirse en el fundamento de nuevos modelos de convivencia. El resultado debería ser un Derecho de Familia basado en la elección del individuo y en la diversidad.

\begin{abstract}
The recognition of marriage between same sex is a step towards ensuring the dignity and the free development of the personality. But marriage reflects a model designed according to the interests and patterns of the heterosexual majority. Therefore, its extension to gays and lesbians also have a questionable effect «normalizing». Instead of this response assimilationist, the free development of affectivity and sexuality should become the basis for new models of coexistence. The result should be family law based on individual choice and diversity.
\end{abstract}

